\title{
Development of a functional rehabilitation intervention for post knee arthroplasty patients: Community based Rehabilitation post Knee Arthroplasty (CORKA) trial.
}

Authors

\author{
J.Room ${ }^{1+2}$, M.Batting ${ }^{1}$, K.L. Barker ${ }^{1+2}$
}

Institutions 1: Physiotherapy Research Unit, Nuffield Orthopaedic Centre, Oxford University Hospitals NHS Ft, Oxford.

2: Nuffield Department of Orthopaedics, Rheumatology and Musculoskeletal Sciences, University of Oxford, Oxford

\begin{abstract}
Knee osteoarthritis is a common cause of disability in older people and knee replacement surgery in the UK is increasing. The CORKA trial is a randomised controlled trial of rehabilitation targeted at patients identified as being at risk of a poor outcome after knee arthroplasty. This paper describes the development and delivery of the CORKA intervention. It was informed by current evidence, relevant guidelines, expert and patient opinion, practical considerations and a pilot study. The intervention is a multicomponent rehabilitation programme with the main component being an exercise programme delivered to participants in their own home. It includes functional task practice, strategies to improve adherence and where appropriate the provision of appropriate aids and equipment.
\end{abstract}

Keywords: Knee arthroplasty; Rehabilitation; Intervention development; Randomised controlled trial; Therapy

\section{Introduction}

Osteoarthritis (OA) is the commonest cause of disability in older people ${ }^{1}$ and painful knee OA affects $10 \%$ of people in the UK over $55^{2}$. National outcome data shows a steady increase in patients undergoing knee arthroplasty (KA) increasing by $3.8 \%$ in the last year ${ }^{3}$. It is known that outcome following KR is multi-faceted; around $15 \%$ of patients do not report a good outcome following KR with on-going pain and mobility problems which reduce their ability to be active after their surgery ${ }^{4}$. There is a strong theoretical underpinning with some evidence from small randomised controlled trials, cohort studies and clinical practice to support an intervention focussed on improving strength, balance and functional activity to optimise post-operative rehabilitation and return to functional activities $^{5-10}$

\section{CORKA Trial Overview}

The COmmunity-based Rehabilitation after Knee Arthroplasty (CORKA) trial is a prospective two armed individually randomised controlled trial (RCT), targeted at patients identified as being at risk of poor outcome after KA with blinded outcome assessment at baseline, 6 and 12 months. The primary outcome is function measured by the Lower Limb Functional Disability Index (LLFDI) at 12 months. A full description of the trial has been previously outlined ${ }^{11}$. A flow diagram of the study can be seen in figure1. Recruitment was completed in January 2018 with 620 participants. 
Figure 1. CORKA trial flow chart

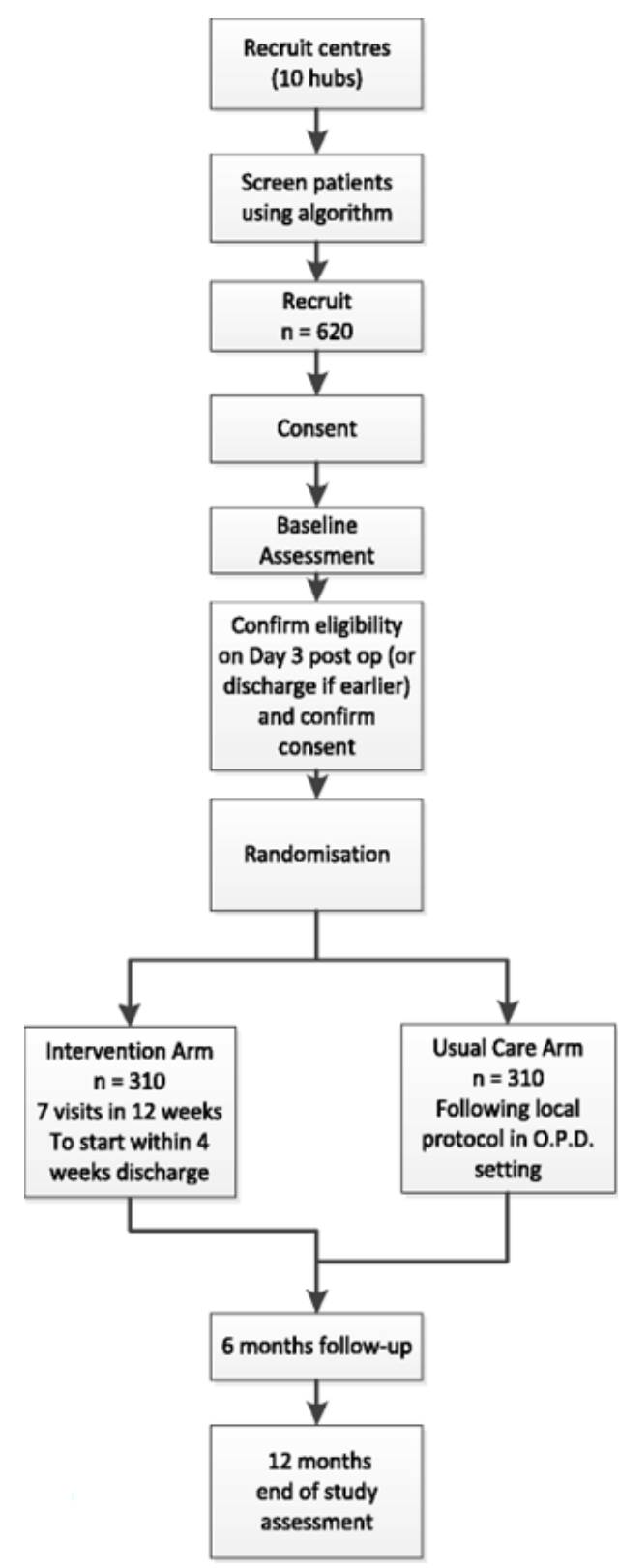

\section{Development of the Intervention}

This paper follows the Medical Research Council guidelines for complex interventions ${ }^{12}$ and is reported in accordance with the Template for Intervention Description and Replication (TIDiER) checklist ${ }^{13}$ and the Consensus on Exercise Reporting Template (CERT) ${ }^{14}$.

The development of the intervention drew from several sources. These included identifying current exercise guidelines, exploring the evidence base on rehabilitation post-arthroplasty and seeking expert and patient opinion. These approaches were discussed and refined at an intervention development day, attended by research staff, physiotherapists and occupational therapists.

Factors associated with the design, content, and delivery of the intervention was discussed, and a draft intervention proposed. The intervention was then reviewed, refined, and tested for delivery in a pilot phase in a clinical NHS setting, including patient feedback. The various steps that were taken are outlined below and are represented in figure 2 .

\section{Guidelines}

There are currently no exercise guidelines specifically for patients following KA. Therefore exercise guidelines for adults 65 years and older or adults aged 50-64 who have either a chronic condition or functional limitations ${ }^{15,16}$ were considered. It is recommend accumulating five sessions of 30 minutes moderate intensity physical activity a week in at least 10 minute bouts ${ }^{16}$.

Figure 2. Intervention development considerations

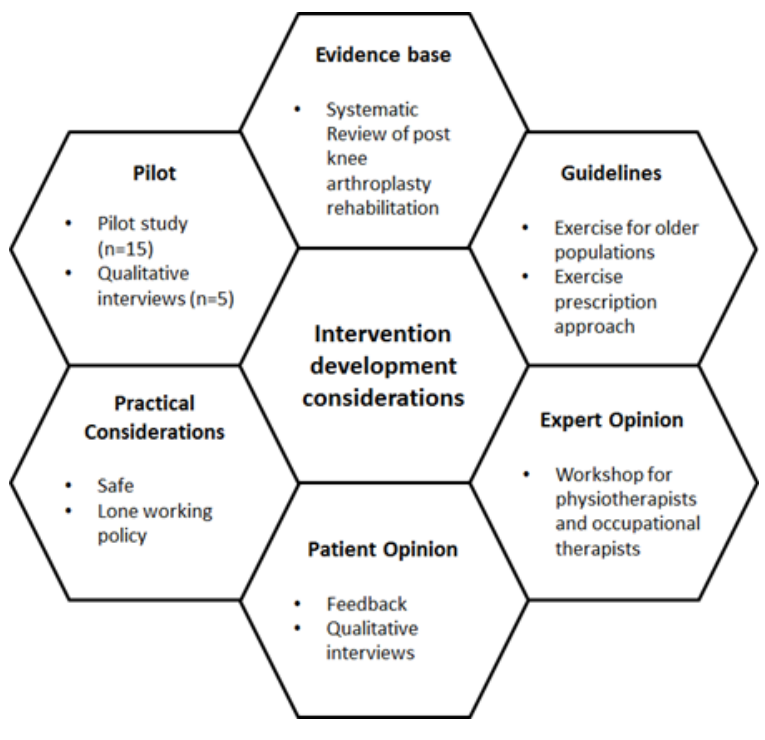

\section{Evidence base}

Prior to the intervention development a systematic search of the literature was conducted on rehabilitation post KA. The relevant papers informing the intervention design are displayed in table 1. 
Table 1 Key papers used in the intervention development

\begin{tabular}{|c|c|c|c|}
\hline Author & Design & $\begin{array}{l}\text { Conclusion or key } \\
\text { considerations }\end{array}$ & $\begin{array}{l}\text { Relevant Intervention } \\
\text { component }\end{array}$ \\
\hline Su et al $2010^{17}$ & Review & $\begin{array}{l}\text { Stiffness a frequent } \\
\text { complications following } \\
\text { TKA }\end{array}$ & $\begin{array}{l}\text { Range of movement } \\
\text { exercises }\end{array}$ \\
\hline $\begin{array}{l}\text { Fitzsimmonds et al } \\
2010^{18}\end{array}$ & Systematic Review & $\begin{array}{l}\text { Stiffness is a common } \\
\text { problem after TKA }\end{array}$ & $\begin{array}{l}\text { Range of movement } \\
\text { exercises }\end{array}$ \\
\hline Bhave et al $2005^{19}$ & Cohort & $\begin{array}{l}\text { Functional limitations } \\
\text { can follow knee } \\
\text { arthroplasty. A } \\
\text { structured programme } \\
\text { may be required for } \\
\text { some patients. }\end{array}$ & $\begin{array}{l}\text { Range of movement } \\
\text { exercises }\end{array}$ \\
\hline Stratford et al $2010^{20}$ & Cohort & $\begin{array}{l}\text { The greatest } \\
\text { improvement in knee } \\
\text { ROM took place during } \\
\text { first } 12 \text { weeks post- } \\
\text { arthroplasty }\end{array}$ & $\begin{array}{l}\text { Range of movement } \\
\text { exercises }\end{array}$ \\
\hline Rowe et al $2000^{21}$ & Cohort & $\begin{array}{l}\text { It is suggested that } 110 \\
\text { degrees of flexion is a } \\
\text { suitable goal for knee } \\
\text { rehabilitation }\end{array}$ & $\begin{array}{l}\text { Range of movement } \\
\text { exercises }\end{array}$ \\
\hline Piva et al $2011^{22}$ & Cross section & $\begin{array}{l}\text { Hip abduction strength } \\
\text { can influence physical } \\
\text { function post- } \\
\text { arthroplasty }\end{array}$ & Strengthening \\
\hline $\begin{array}{l}\text { Bade and Stevens- } \\
\text { Lapsley } 2011^{23}\end{array}$ & Cohort & $\begin{array}{l}\text { Early high intensity } \\
\text { rehabilitation post-TKA } \\
\text { can lead to better } \\
\text { functional performance }\end{array}$ & Strengthening \\
\hline Liao et al $2013^{24}$ & $\mathrm{RCT}$ & $\begin{array}{l}\text { Balance training } \\
\text { resulted in a significant } \\
\text { change in } 10 \mathrm{~m} \text { walk and } \\
\text { timed up-and-go test }\end{array}$ & Balance \\
\hline Pozzi et al $2013^{25}$ & Systematic Review & $\begin{array}{l}\text { Optimal physiotherapy } \\
\text { should include } \\
\text { strengthening and } \\
\text { intensive functional } \\
\text { exercises }\end{array}$ & $\begin{array}{l}\text { Strengthening } \\
\text { Functional task practice }\end{array}$ \\
\hline Stevens et al $2003^{26}$ & Cohort & $\begin{array}{l}\text { Patients with knee OA } \\
\text { have reduced } \\
\text { quadriceps strength, } \\
\text { and weakness persists } \\
\text { after surgery. }\end{array}$ & Strengthening \\
\hline Walsh et al $1998^{8}$ & Cohort & $\begin{array}{l}\text { One year post-TKA } \\
\text { physical impairments } \\
\text { and functional }\end{array}$ & Strengthening \\
\hline
\end{tabular}




\begin{tabular}{|c|c|c|c|}
\hline & & limitations can persist & \\
\hline Mizner et al $2005^{27}$ & Cohort & $\begin{array}{l}\text { Quadriceps strengthen } \\
\text { is highly correlated with } \\
\text { functional performance }\end{array}$ & Strengthening \\
\hline Pandy et al $2010^{28}$ & Review & $\begin{array}{l}\text { Hip and calf } \\
\text { musculature play an } \\
\text { important role in gait }\end{array}$ & $\begin{array}{l}\text { Strengthening } \\
\text { Gait skills }\end{array}$ \\
\hline Lee et al $2014^{29}$ & Cross section & $\begin{array}{l}\text { There is a weak } \\
\text { correlation between } \\
\text { lower limb strength and } \\
\text { the Y-balance test }\end{array}$ & $\begin{array}{l}\text { Strength } \\
\text { Balance }\end{array}$ \\
\hline Moffet et al $2004^{10}$ & RCT & $\begin{array}{l}\text { Intensive functional } \\
\text { rehabilitation was } \\
\text { effective at improving } \\
\text { short and midterm } \\
\text { functional ability }\end{array}$ & Strengthening \\
\hline Coulter et al $2009^{30}$ & Cohort & $\begin{array}{l}\text { No significant } \\
\text { differences in WOMAC } \\
\text { between class or one to } \\
\text { one physiotherapy after } \\
\text { joint replacement } \\
\text { surgery (both groups } \\
\text { utilised strengthening } \\
\text { exercises) }\end{array}$ & Strengthening \\
\hline Knoop et al $2011^{31}$ & Narrative Review & $\begin{array}{l}\text { Knee proprioception is } \\
\text { decreased in people } \\
\text { with knee OA }\end{array}$ & Balance \\
\hline Mandeville et al $2008^{32}$ & Cohort & $\begin{array}{l}\text { TKR can affect gait } \\
\text { stability after surgery }\end{array}$ & $\begin{array}{l}\text { Balance } \\
\text { Gait skills }\end{array}$ \\
\hline Kearns et al $2008^{33}$ & Cohort & $\begin{array}{l}\text { From a consecutive } \\
\text { series of } 1341 \text { TKA } \\
\text { patients, } 78(7 \%) \\
\text { reported falling }\end{array}$ & Balance \\
\hline Piva et al $2010^{5}$ & Pilot RCT & $\begin{array}{l}\text { Feasibility of balance } \\
\text { training post-TKA } \\
\text { supported by high } \\
\text { adherence and low } \\
\text { drop out }\end{array}$ & Balance \\
\hline McClelland et al $2007^{34}$ & Systematic Review & $\begin{array}{l}\text { TKA patients have } \\
\text { altered gait patterns }\end{array}$ & Gait skills \\
\hline Heiberg et al $2010^{35}$ & Cohort & $\begin{array}{l}\text { Post-TKA patient can } \\
\text { experience difficulty } \\
\text { with strenuous } \\
\text { activities including } \\
\text { walking long distances }\end{array}$ & $\begin{array}{l}\text { Gait skill } \\
\text { Graduated walking } \\
\text { programme }\end{array}$ \\
\hline Wiik et al $2013^{36}$ & Cohort & $\begin{array}{l}\text { Gait parameters after } \\
\text { UKR are much closer to } \\
\text { normal compared to } \\
\text { TKR, but still not as }\end{array}$ & $\begin{array}{l}\text { Gait skills } \\
\text { Graduated walking } \\
\text { programme }\end{array}$ \\
\hline
\end{tabular}




\begin{tabular}{|c|c|c|c|}
\hline & & good as controls & \\
\hline Turcot et al $2013^{37}$ & Cohort & $\begin{array}{l}\text { Gait parameters impact } \\
\text { satisfaction post-TKA }\end{array}$ & $\begin{array}{l}\text { Graduated walking } \\
\text { programme }\end{array}$ \\
\hline $\begin{array}{l}\text { Bruun-Olsen et al } \\
2013^{38}\end{array}$ & RCT & $\begin{array}{l}\text { A walking skills } \\
\text { programme } \\
\text { demonstrated a better } \\
6 \text { minute walk post-TKA }\end{array}$ & $\begin{array}{l}\text { Gait skills } \\
\text { Graduated walking } \\
\text { programme }\end{array}$ \\
\hline Philbin et al $1995^{39}$ & Cross section & $\begin{array}{l}\text { Patients with end-stage } \\
\text { lower extremity OA are } \\
\text { severely deconditioned }\end{array}$ & $\begin{array}{l}\text { Graduated walking } \\
\text { programme }\end{array}$ \\
\hline Ries et al $1996^{40}$ & Cohort & $\begin{array}{l}\text { Cardiovascular fitness } \\
\text { can improve at one year } \\
\text { and two years post-TKA }\end{array}$ & $\begin{array}{l}\text { Graduated walking } \\
\text { programme }\end{array}$ \\
\hline Naylor and Ko $2012^{41}$ & $\begin{array}{l}\text { Mixed methods study } \\
\text { (Nested within a RCT) }\end{array}$ & $\begin{array}{l}\text { Patients post-TKA are } \\
\text { able to exercise at } \\
\text { moderately hard } \\
\text { intensity }\end{array}$ & $\begin{array}{l}\text { Graduated walking } \\
\text { programme } \\
\text { Strengthening }\end{array}$ \\
\hline Harmer et al $2009^{42}$ & RCT & $\begin{array}{l}\text { Land-based or water- } \\
\text { based rehabilitation } \\
\text { delivered after TKA, } \\
\text { offer similar outcomes }\end{array}$ & $\begin{array}{l}\text { Graduated walking } \\
\text { programme }\end{array}$ \\
\hline Meier et al $2008^{6}$ & Review & $\begin{array}{l}\text { Post-TKA quadriceps } \\
\text { muscle impairment can } \\
\text { contribute to functional } \\
\text { limitations }\end{array}$ & $\begin{array}{l}\text { Functional task practice } \\
\text { Strengthening }\end{array}$ \\
\hline $\begin{array}{l}\text { Bade and Stevens- } \\
\text { Lapsley } 2012^{43}\end{array}$ & Review & $\begin{array}{l}\text { Rehabilitation } \\
\text { programmes that utilise } \\
\text { higher intensity, } \\
\text { progressive resistance } \\
\text { strengthening } \\
\text { demonstrate superior } \\
\text { long term strength and } \\
\text { functional gains }\end{array}$ & $\begin{array}{l}\text { Functional task practice } \\
\text { Strengthening }\end{array}$ \\
\hline Noble et al $2005^{7}$ & Cross section & $\begin{array}{l}\text { TKA patients experience } \\
\text { substantial functional } \\
\text { impairment }\end{array}$ & Functional task practice \\
\hline Bade et al $2010^{44}$ & Cohort & $\begin{array}{l}\text { Persistent impairments } \\
6 \text { months after TKA } \\
\text { suggest more intensive } \\
\text { therapeutic approaches } \\
\text { may be needed }\end{array}$ & Functional task practice \\
\hline Minns Lowe et al $2007^{9}$ & Systematic Review & $\begin{array}{l}\text { Interventions including } \\
\text { functional } \\
\text { physiotherapy exercise } \\
\text { result in short term } \\
\text { benefit post-TKA }\end{array}$ & Functional task practice \\
\hline
\end{tabular}




\section{Rationale underlying the CORKA intervention}

\section{Range of Movement (ROM)}

Following KA surgery there is potential for a loss of both flexion and extension ${ }^{19,20}$. A range of $0-110^{\circ}$ is suggested to allow most normal functional activities ${ }^{21}$. It is likely that a significant proportion of any increase in ROM will occur in the initial 12 weeks post-surgery ${ }^{20}$ and several studies have included ROM exercises within their post-operative protocols ${ }^{22-24}$. Stiffness can also be a complication ${ }^{17}$ and up to $60 \%$ of patients undergoing total KA may experience stiffness ${ }^{18}$

\section{Strengthening}

It is known that those with knee OA may have decreased quadriceps strength ${ }^{26}$. It is common to find these strength deficit persisting following for a long time following $\mathrm{KA}^{25}$. Knee flexor and extensor peak muscle torque has been found to be lower in people one year after KA compared to age matched controls ${ }^{8}$. Muscle strength is an important consideration for this population as strength and functional performance are closely linked. For example, quadriceps strength has been linked with the ability to move from sitting to standing, or stair climbing ${ }^{27}$. Hip abductor strength has been correlated with rising from a chair, climbing stairs, walking and changing direction ${ }^{22}$. In addition hip and calf strength play an important role in gait and balance ${ }^{28,29}$. Previous interventions for this population have included strengthening exercises, with focus on quadriceps, hamstrings, hip

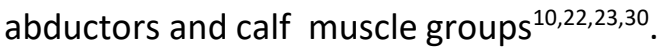

\section{Balance}

Knee replacement surgery can affect gait, stability and balance ${ }^{32}$, and falling can be a problem following $\mathrm{KA}^{33}$. A pilot study has looked at adding balance training to functional training after KA. Although this was a pilot study and therefore underpowered to detect changes in groups, the authors reported that the balance training group demonstrated high adherence, low drop out and importantly no adverse events ${ }^{5}$. A RCT investigating the effects of functional training with or without balance after KA, found that additional balance training provided significantly better outcomes including $10 \mathrm{~m}$ walk, Timed Up and Go (TUG), stair climb test and chair rise test ${ }^{24}$.

\section{Gait Skills and Aerobic Exercise}

A systematic review of gait analysis post total KA concluded that patients following surgery have altered gait patterns ${ }^{34}$. Problems with walking after KA are common. These include specific gait deficits linked to underlying problems such as pain or reduced ROM and general problems such as decreased walking speed and endurance ${ }^{8,34,35}$. These difficulties may persist at one year post surgery

${ }^{8}$. Unicompartmental knee replacements are more likely to allow a gait pattern closer to normal, but they still demonstrate an altered gait pattern ${ }^{36}$. Gait outcomes contribute to patient satisfaction ${ }^{37}$, making gait an important consideration in post KA rehabilitation. An RCT that compared walking skills with usual physiotherapy, reported short and longer term functional mobility as 'better in the walking skills group' 38 . Walking may also need to be considered from a wider cardiovascular perspective, particularly as it is known that those with end stage OA of the lower limbs are likely to be physically deconditioned ${ }^{39,40}$. This is likely to be exacerbated by reduced mobility immediately post-op. Heart rate response, in addition to other factors affecting exercise performance have been investigated in participants after KA. ${ }^{41}$ It was found that moderate intensity exercise was both safe 
and tolerable for this population. Other interventions post KA have included aerobic exercise such as cycling on a static bike and treadmill walking ${ }^{30,42}$.

\section{Functional Exercise}

Functional limitations, persisting beyond the post-operative period, can be experience by patients after $K A^{45,43}$. A year after surgery patients are likely to be significantly slower when walking and climbing the stairs, in addition to having greater functional impairments on tasks involving kneeling or squatting compared to matched controls ${ }^{7,8}$. Function as measured by the stair climb test, TUG test, 6 minute walk test, and single leg stance has been found to be worse in those post knee replacement, compared to healthy adults at 1, 3 and 6 months post-surgery ${ }^{44}$. In 2007 a systematic review evaluated the effectiveness of exercise after KA. It supported the use of functional physiotherapy exercise interventions to obtain short term benefit ${ }^{9}$. It showed that at 3 to 4 months a small to moderate effect on functional outcome, in addition to a small to moderate effect on quality of life and joint ROM were reported, although no such benefits were found at one year postoperatively. Since this review, further studies have investigated restoration of function post KA ${ }^{43}$, and a further systematic review of exercise post KA conducted in 2013, recommended that physiotherapy should include both strengthening and intensive functional exercises ${ }^{25}$.

\section{Workshops}

An initial draft version of the CORKA intervention was compiled on the basis of the guidelines and evidence base described above. The intervention programme, exercise progression strategies and patient materials were reviewed by physiotherapists and occupational therapists in the form of workshops. Following the workshops, feedback was given on all aspects of the intervention, and changes were made to both the intervention and patient materials.

\section{Pilot Phase}

Once a final version of the intervention had been developed it was tested in a pilot phase, consisting of 15 participants. After completion of the pilot 3 participants and 2 clinicians were interviewed following treatment, seeking their feedback on the content of the intervention and the mode of delivery. The resulting feedback led to modifications to the patient materials and intervention procedures. The modifications included the need to retake some of the photographs for the exercise sheets to make them 'brighter' and more 'vibrant', in addition to providing a space for comments on the exercise sheets.

\section{CORKA Interventions}

The CORKA trial consisted of two intervention arms, usual care and the CORKA intervention. These are described below.

\section{Usual care}

Participants allocated to usual care will receive routine post-operative physiotherapy as offered by the local centre. It is recognised that usual care can vary considerably geographically ${ }^{46}$, however it is likely to include some of the following; written advice on the home exercises given on discharge from hospital, between 1-6 sessions of outpatient physiotherapy, class based exercise sessions or 
hydrotherapy and home requirements assessed by an occupational therapist to identify any potential barriers to discharge. To standardise usual care as much as possible, participants will be expected to attend at least one, and no more than six, sessions of usual care.

\section{CORKA intervention}

The CORKA intervention is a multicomponent rehabilitation programme. The aim is to improve both the function and participation in activities in those at risk of a poor outcome following KA. The main component of the intervention is an exercise programme delivered to participants in their own home, with the addition of functional task practice, consideration of adherence approaches, and the provision of appropriate aids and equipment. The intervention starts within 4 weeks of surgery and consists of an initial assessment followed by up to 6 subsequent sessions. It is delivered by a mix of qualified staff and rehabilitation assistants. All aspects of this intervention are outlined further below.

\section{Home exercise programme}

The CORKA trial exercise programme consists of groups of possible exercises ordered into specific sections. These sections are 'knee flexion ROM', 'knee extension ROM', 'basic quadriceps strengthening', 'strengthening - quadriceps', 'strengthening - hamstrings', 'strengthening - hip abductors', 'strengthening - calf', 'balance', 'gait skills'. A range of different exercises are included in each section, with the aim of including one exercise from each section, meaning the intervention can be tailored to each individual patient. All exercises can be viewed in appendix 1 .

\section{Functional task practice}

During the participants initial assessment the physiotherapist will focus on tasks that are identified as being problematic. The exercise programme will then be tailored to the individuals' needs and goals. In addition to this other specific tasks will be practiced. If necessary, techniques such as breaking down the task and identifying specific components will be used as part of a practical problem solving approach. These tasks can also be demonstrated and practiced within treatment sessions. To reinforce the importance of task practice written advice will be included in the participants exercise diary. Participants will be asked to follow the advice given when carrying out the task in their daily life. Tasks can then be reviewed, progressed or changed at subsequent sessions.

\section{Graduated walking programme}

The most practical and relevant way to include moderate intensity aerobic exercise within the intervention, and to improve walking endurance is through a graduated walking programme. It is clear that participants will demonstrate a wide range of mobility levels at baseline. Therefore the aim of the graduated walking programme is to increase participants walking time or distance. At session 3 of the intervention participants will be asked about their walking, in relation to time or distance they are currently able to manage, they will then be asked to increase this time or distance gradually, considering any pain and swelling. This will be reviewed at subsequent sessions. 


\section{Prescription and Progression}

Prescription and progression of exercises will be linked to treatment algorithms and decision aids. These are described and outlined in Table 2. RPE refers to Rating of Perceived Exertion scale ${ }^{47}$, an 11 point scale where participants can rate how hard they feel they are working.

Table 2. Prescription and progression of exercise

\begin{tabular}{|c|c|c|c|c|}
\hline Exercise type & Reps and Sets & $\begin{array}{l}\text { Decrease } \\
\text { intensity/difficulty }\end{array}$ & $\begin{array}{l}\text { Maintain } \\
\text { intensity/difficulty }\end{array}$ & $\begin{array}{l}\text { Increase } \\
\text { intensity/difficulty }\end{array}$ \\
\hline $\begin{array}{l}\text { Strengthening } \\
\text { exercises }\end{array}$ & $\begin{array}{l}\text { 6-12 Reps } \\
\text { 2-3 Sets } \\
5 \mathrm{Sec} \text { hold (if } \\
\text { required) }\end{array}$ & $\begin{array}{l}\text { RPE } \geq 5 \\
\text { Unable to complete } 6 \\
\text { repetitions of exercise with } \\
\text { good form } \\
\text { Increase in pain lasting } \\
\text { longer than } 2 \text { hours post } \\
\text { exercise } \\
\text { Significant increase in } \\
\text { swelling }\end{array}$ & $\begin{array}{l}\text { Able to complete 6-12 } \\
\text { repetitions with good } \\
\text { form }\end{array}$ & $\begin{array}{l}\text { Can complete more } \\
\text { than } 12 \text { repetitions } \\
\text { with good form }\end{array}$ \\
\hline $\begin{array}{l}\text { Balance } \\
\text { exercises }\end{array}$ & $\begin{array}{l}3 \text { Reps } \\
\text { 2-3 Sets } \\
30 \text { Second hold }\end{array}$ & $\begin{array}{l}\text { Participant at risk of falling } \\
\text { Pain lasting longer than } 2 \\
\text { hours post exercise } \\
\text { A significant increase in } \\
\text { swelling }\end{array}$ & $\begin{array}{l}\text { Exercise challenging for } \\
\text { participants but not } \\
\text { putting them at risk of } \\
\text { falling }\end{array}$ & $\begin{array}{l}\text { Exercise is not } \\
\text { challenging for } \\
\text { participant }\end{array}$ \\
\hline $\begin{array}{l}\text { Range of } \\
\text { movement } \\
\text { exercises }\end{array}$ & $\begin{array}{l}\text { 10-15 Reps } \\
\text { Sets } \\
\text { If stretch selected 3-5 } \\
\text { Reps with 30-60 Sec } \\
\text { hold }\end{array}$ & $\begin{array}{l}\text { Participant or therapist feel } \\
\text { exercise isn't being } \\
\text { performed correctly }\end{array}$ & $\begin{array}{l}\text { Participant and } \\
\text { therapists happy } \\
\text { exercise is being } \\
\text { performed correctly }\end{array}$ & $\begin{array}{l}\text { Participant or } \\
\text { therapist feel exercise } \\
\text { isn't being performed } \\
\text { correctly }\end{array}$ \\
\hline Gait skills & $\begin{array}{l}\text { Reps and sets as } \\
\text { required based on } \\
\text { assessment of the } \\
\text { patient and exercise } \\
\text { selected }\end{array}$ & $\begin{array}{l}\text { Exercise too challenging for } \\
\text { participant, putting } \\
\text { participant at risk of falling }\end{array}$ & $\begin{array}{l}\text { Exercise challenging for } \\
\text { participants but not } \\
\text { putting them at risk of } \\
\text { falling }\end{array}$ & $\begin{array}{l}\text { Exercise is not } \\
\text { challenging for } \\
\text { participant }\end{array}$ \\
\hline Walking & $\begin{array}{l}\text { Recommendation to } \\
\text { gradually increase } \\
\text { walking distance/time } \\
\text { from session } 3 \\
\text { onwards }\end{array}$ & $\begin{array}{l}\text { RPE } \geq 5 \\
\text { Pain lasting longer than } 2 \\
\text { hours post exercise } \\
\text { A significant increase in } \\
\text { swelling }\end{array}$ & RPE 3-4 & $\mathrm{RPE}<3$ \\
\hline Task practice & $\begin{array}{l}\text { To practice } 1 \text { to } 3 \\
\text { tasks as required } \\
\text { during daily life }\end{array}$ & $\begin{array}{l}\text { Task practice too } \\
\text { challenging for participant, } \\
\text { putting participant at risk of } \\
\text { falling }\end{array}$ & $\begin{array}{l}\text { Task practice challenging } \\
\text { for participants but not } \\
\text { putting them at risk of } \\
\text { falling }\end{array}$ & $\begin{array}{l}\text { Task practice is not } \\
\text { challenging for } \\
\text { participant }\end{array}$ \\
\hline
\end{tabular}




\section{Exercise duration and frequency}

It is envisaged that the exercise programme will take between 15-25 minutes to complete.

Participants will be advised that they can perform this as one block or spread throughout the day. They will be asked to perform their exercises daily, although we recognise this may not be possible for everyone.

\section{Modifications}

Therapists and rehabilitation assistants will be encouraged to use their clinical reasoning skills when delivering the intervention. If staff members feel that it is unsafe or not appropriate to give a participant an exercise from a particular section of the intervention, then they will be advised not to. If they feel a participant needs additional exercise(s) from a particular section in the intervention, e.g. to encourage flexion in a stiff knee, then they will be advised to do this. Staff members will be asked to record any modifications they make on treatment logs that will be sent back to the central trial team.

\section{Information}

In addition to the exercise programme participants will be given an information booklet, which comprises of information about pain and swelling, wound management, scar massage, expected symptoms, slips trips and falls, walking, driving, kneeling, stairs, exercise advice, returning to work, and returning to sports or leisure activities.

\section{Adherence}

Several adherence strategies are built into the intervention. These included goal setting, an exercise diary, and a behavioural contract. Goal setting includes discussion with the participants and therapists about goals that are important to the individual. These goals will be recorded in the relevant section in the participant materials, alongside a plan to practice undertaking tasks related to the goal, to follow their tailored exercise programme, and to keep a record of their exercises in the exercise diary. Goals can be reviewed in subsequent sessions as required. In relation to goals the participant material contains a behavioural contract. Participants will be asked when they will undertake their exercise programme, where they will perform their exercise programme, and who can help them achieve their goal. The therapist and participant can then sign this form. Furthermore participants will be given an exercise diary where they can record the exercise they have undertaken daily.

\section{Skill mix}

This intervention will be undertaken using both qualified therapists and rehabilitation assistants. At the initial appointment the therapist and assistant will undertake the assessment. Subsequent sessions will be undertaken by the rehabilitation assistant only, with the qualified staff member visiting for an additional session mid-way through the intervention. All therapists will be either UK registered physiotherapists or occupational therapists. NHS banding will range from 5-7 for qualified therapists and 3-4 for therapy assistants

\section{Training}


All staff delivering the CORKA intervention will receive training. This will consisted of a 2-3 hour training session, including instructions on how to treat participants according to the trial protocol, how to select and progress exercise in line with the protocol, and how to complete trial paperwork. No elements of the intervention are beyond the scope of normal practice for those who will deliver the intervention. Staff members will be provided with a therapist manual which outlines the intervention in detail and included a guide for each session.

\section{Safety and Serious Adverse Events}

At all sites staff members will be encouraged to consider the safety of the participant and themselves. A significant consideration in a trial such as CORKA, is that staff will be working alone. Therefore all staff members will be asked to follow the lone working policy of their own organisation and encouraged to report anything they felt constitutes an adverse event or serious adverse event. In order to make this process less burdensome they will be encouraged to contact the central team in Oxford to discuss any questions or concerns.

\section{Intervention Fidelity}

Fidelity of the intervention will be monitored by visits form the research physiotherapists on the CORKA trial team to observe the intervention sessions. A pre-defined form will be used to check all aspects of the intervention, as outlined in the protocol.

\section{Conclusion}

This paper has outlined the development, and content of a multi-component functional rehabilitation intervention for participants at risk of a poor outcome after KA. The effectiveness of this intervention compared to usual care will be reported at the end of the CORKA trial. 


\section{References}

1. Martin J, Meltzer H, Elliot D. OPCS Surveys of Disability in Great Britain. Report 1. The Prevelance of Diasbility among Adults. London; 1988.

2. Peat G, McCarney R, Croft P. Knee pain and osteoarthritis in older adults: a review of community burden and current use of primary health care. Ann Rheum Dis. 2001;60(2):91-97. doi:10.1136/ard.60.2.91.

3. National Joint Registry. 14th Annual Report. Vol 1821.; 2017. http://www.njrreports.org.uk/Portals/O/PDFdownloads/NJR 14th Annual Report 2017.pdf.

4. Jones CA, Beaupre LA, Johnston DWC, Suarez-Almazor ME. Total Joint Arthroplasties: Current Concepts of Patient Outcomes after Surgery. Rheum Dis Clin North Am. 2007;33(1):71-86. doi:10.1016/j.rdc.2006.12.008.

5. Piva SR, Gil AB, Almeida GJM, DiGioia AM, Levison TJ, Fitzgerald GK. A balance exercise program appears to improve function for patients with total knee arthroplasty: a randomized clinical trial. Phys Ther. 2010;90(6):880-894. doi:10.2522/ptj.20090150.

6. Meier W, Mizner RL, Marcus RL, Dibble LE, Peters C, Lastayo PC. Total knee arthroplasty: muscle impairments, functional limitations, and recommended rehabilitation approaches. $J$ Othopaedic Sport Phys Ther. 2008;38(5):246-256. doi:10.2519/jospt.2008.2715.

7. Noble PC, Gordon MJ, Weiss JM, Reddix RN, Conditt M a, Mathis KB. Does Total Knee Replacement Restore Normal Knee Function? Clin Orthop Relat Res. 2005;431:157-165. doi:10.1097/01.blo.0000150130.03519.fb.

8. Walsh M, Woodhouse L, Thomas S, Finch E. Physical impairments and functional limitations: a comparison of individuals 1 year after total knee arthroplasty with control subjects. Phys Ther. 1998;78:248-258. http://ptjournal.apta.org/content/78/3/248.short. Accessed November 24, 2014.

9. Minns Lowe CJ, Barker KL, Dewey M, Sackley CM. Effectiveness of physiotherapy exercise after knee arthroplasty for osteoarthritis: Systematic review and meta-analysis of randomised controlled trials. Br Med J. 2007;335(7624):812-815. doi:10.1136/bmj.39311.460093.BE.

10. Moffet H, Collet J-P, Shapiro SH, Paradis G, Marquis F, Roy L. Effectiveness of intensive rehabilitation on functional ability and quality of life after first total knee arthroplasty: a single-blind randomized controlled trial. Arch Phys Med Rehabil. 2004;85(4):546-556. doi:10.1016/j.apmr.2003.08.080.

11. Barker KL, Beard D, Price A, et al. COmmunity-based Rehabilitation after Knee Arthroplasty (CORKA): Study protocol for a randomised controlled trial. Trials. 2016;17(1):1-11. doi:10.1186/s13063-016-1629-1.

12. Craig P, Dieppe P, Macintyre S, Mitchie S, Nazareth I, Petticrew M. Developing and evaluating complex interventions: the new Medical research council guidance. BMJ. 2008;337(337):979983. doi:10.1136/bmj.a1655.

13. Hoffmann TC, Glasziou PP, Boutron I, et al. Better reporting of interventions: template for intervention description and replication (TIDieR) checklist and guide. $B M J$. 2014;348(mar07_3):g1687.doi:10.1136/bmj.g1687.

14. Slade SC, Dionne CE, Underwood M, Buchbinder R. Consensus on Exercise Reporting 
Template (CERT): Explanation and Elaboration Statement. Br J Sports Med. 2016;50(23):14281437. doi:10.1136/bjsports-2016-096651.

15. Garber CE, Blissmer B, Deschenes MR, et al. American College of Sports Medicine position stand. Quantity and quality of exercise for developing and maintaining cardiorespiratory, musculoskeletal, and neuromotor fitness in apparently healthy adults: guidance for prescribing exercise. Med Sci Sports Exerc. 2011;43(7):1334-1359. doi:10.1249/MSS.0b013e318213fefb.

16. Nelson ME, Rejeski WJ, Blair SN, et al. Physical activity and public health in older adults: recommendation from the American College of Sports Medicine and the American Heart Association. Circulation. 2007;116(9):1094-1105. doi:10.1161/CIRCULATIONAHA.107.185650.

17. Su EP, Su SL, Della Valle AG. Stiffness after TKR: how to avoid repeat surgery. Orthopedics. 2010;33(9):658.

18. Fitzsimmons SE, Vazquez EA, Bronson MJ. How to treat the stiff total knee arthroplasty?: A systematic review. Clin Orthop Relat Res. 2010;468(4):1096-1106. doi:10.1007/s11999-010$1230-y$.

19. BHAVE A, MONT M, TENNIS S, NICKEY M, STARR R, ETIENNE G. Functional Problems and Treatment Solutions After Total Hip and Knee Joint Arthroplasty. J Bone Jt Surg. 2005;S2:9-21.

20. Stratford $P$, Kennedy $D$, Robarts $S$. Modelling knee range of motion post arthroplasty: clinical applications. Physiother Canada. 2010;62(4):378-387. doi:10.3138/physio.62.4.378.

21. Rowe PJ, Myles CM, Walker C, Nutton R. Knee joint kinematics in gait and other functional activities measured using flexible electrogoniometry: how much knee motion is sufficient for normal daily life? Gait Posture. 2000;12(2):143-155. doi:10.1016/S0966-6362(00)00060-6.

22. Piva SR, Teixeira PEP, Almeida GJM, et al. Contribution of hip abductor strength to physical function in patients with total knee arthroplasty. Phys Ther. 2011;91(2):225-233. doi:10.2522/ptj.20100122.

23. Bade MJ, Stevens-Lapsley JE. Early high-intensity rehabilitation following total knee arthroplasty improves outcomes. J Orthop Sports Phys Ther. 2011;41(12):932-941. doi:10.2519/jospt.2011.3734.

24. Liao C-D, Liou T-H, Huang Y-Y, Huang Y-C. Effects of balance training on functional outcome after total knee replacement in patients with knee osteoarthritis: a randomized controlled trial. Clin Rehabil. 2013;27(8):697-709. doi:10.1177/0269215513476722.

25. Pozzi F, Snyder-Mackler L, Zeni J. Physical exercise after knee arthroplasty: a systematic review of controlled trials. Eur J Phys .... 2013;49(6):877-892.

http://europepmc.org/abstract/med/24172642. Accessed November 24, 2014.

26. Stevens JE, Mizner RL, Snyder-Mackler L. Quadriceps strength and volitional activation before and after total knee arthroplasty for osteoarthritis. J Orthop Res. 2003;21(5):775-779. doi:10.1016/S0736-0266(03)00052-4.

27. Mizner R, Petterson S, Snyder-Mackler L. Quadriceps strength and the time course of functional recovery after total knee arthroplasty. J Orthop Sport Phys Ther. 2005;35(7):424436. http://www.jospt.org/doi/abs/10.2519/jospt.2005.35.7.424. Accessed November 24, 2014. 
28. Pandy MG, Andriacchi TP. Muscle and Joint Function in Human Locomotion. Vol 12.; 2010. doi:10.1146/annurev-bioeng-070909-105259.

29. Lee D-K, Kim G-M, Ha S-M, Oh J-S. Correlation of the Y-Balance Test with Lower-limb Strength of Adult Women. J Phys Ther Sci. 2014;26(5):641-643. doi:10.1589/jpts.26.641.

30. Coulter CL, Weber JM, Scarvell JM. Group physiotherapy provides similar outcomes for participants after joint replacement surgery as 1-to-1 physiotherapy: a sequential cohort study. Arch Phys Med Rehabil. 2009;90(10):1727-1733. doi:10.1016/j.apmr.2009.04.019.

31. Knoop J, Steultjens MPM, van der Leeden M, et al. Proprioception in knee osteoarthritis: a narrative review. Osteoarthritis Cartilage. 2011;19(4):381-388.

doi:10.1016/j.joca.2011.01.003.

32. Mandeville $D$, Osternig LR, Chou L-S. The effect of total knee replacement surgery on gait stability. Gait Posture. 2008;27(1):103-109. doi:10.1016/j.gaitpost.2007.02.009.

33. Kearns RJ, O'Connor DP, Brinker MR. Management of falls after total knee arthroplasty. Orthopedics. 2008;31(3):225.

34. McClelland J a, Webster KE, Feller J a. Gait analysis of patients following total knee replacement: a systematic review. Knee. 2007;14(4):253-263.

doi:10.1016/j.knee.2007.04.003.

35. Heiberg KE, Bruun-Olsen V, Mengshoel AM. Pain and recovery of physical functioning nine months after total knee arthroplasty. J Rehabil Med. 2010;42(7):614-619.

doi:10.2340/16501977-0568.

36. Wiik A V., Manning V, Strachan RK, Amis AA, Cobb JP. Unicompartmental knee arthroplasty enables near normal gait at higher speeds, unlike total knee arthroplasty. J Arthroplasty. 2013;28(9 SUPPL):176-178. doi:10.1016/j.arth.2013.07.036.

37. Turcot K, Sagawa Y, Fritschy D, Hoffmeyer P, Suvà D, Armand S. How gait and clinical outcomes contribute to patients' satisfaction three months following a total knee arthroplasty. J Arthroplasty. 2013;28(8):1297-1300. doi:10.1016/j.arth.2013.01.031.

38. Bruun-Olsen V, Heiberg KE, Wahl AK, Mengshoel AM. The immediate and long-term effects of a walking-skill program compared to usual physiotherapy care in patients who have undergone total knee arthroplasty (TKA): a randomized controlled trial. Disabil Rehabil. 2013;35(23):2008-2015. doi:10.3109/09638288.2013.770084.

39. Philbin E, Groff G, Ries M, Miller T. Cardiovascular fitness and health in patients with end stage osteoarthritis. Arthritis Rheum. 1995;38(6):799-805.

http://onlinelibrary.wiley.com/doi/10.1002/art.1780380613/abstract. Accessed December 16, 2014.

40. Ries M, Philbin E, Groff G, Sheesley K, Richman J, Lynch F. Improvement in Cardiovascular Fitness after Total Knee Arthroplasty. J Bone Jt Surg. 1996:1696-1701. http://jbjs.org/article.aspx?articleid=23145. Accessed December 16, 2014.

41. Naylor JM, Ko V. Heart rate response and factors affecting exercise performance during home- or class-based rehabilitation for knee replacement recipients: lessons for clinical practice. J Eval Clin Pract. 2012;18(2):449-458. doi:10.1111/j.1365-2753.2010.01596.x.

42. Harmer AR, Naylor JM, Crosbie J, Russell T. Land-based versus water-based rehabilitation 
following total knee replacement: a randomized, single-blind trial. Arthritis Rheum.

2009;61(2):184-191. doi:10.1002/art.24420.

43. Bade MJ, Stevens-Lapsley JE. Restoration of physical function in patients following total knee arthroplasty: an update on rehabilitation practices. Curr Opin Rheumatol. 2012;24(2):208214. doi:10.1097/BOR.0b013e32834ff26d.

44. Bade M, Kohrt W, Stevens-Lapsley J. Outcomes before and after total knee arthroplasty compared to healthy adults. J Orthop Sport Phys Ther. 2010;40(9):559-567. doi:10.2519/jospt.2010.3317.Outcomes.

45. Meier W, Mizner RL, Marcus RL, Dibble LE, Peters C, Lastayo PC. Total knee arthroplasty: muscle impairments, functional limitations, and recommended rehabilitation approaches. $J$ Orthop Sports Phys Ther. 2008;38(5):246-256. doi:10.2519/jospt.2008.2715.

46. Artz N, Dixon S, Wylde V, Beswick A, Blom A, Gooberman-Hill R. Physiotherapy provision following discharge after total hip and total knee replacement: a survey of current practice at high-volume NHS hospitals in England and wales. Musculoskeletal Care. 2013;11(1):31-38. doi:10.1002/msc.1027.

47. Borg G. Borg's Perceived Exertion and Pain Scales.; 1998. doi:10.1097/00005768-19980900000018. 
Appendix 1. CORKA intervention exercises

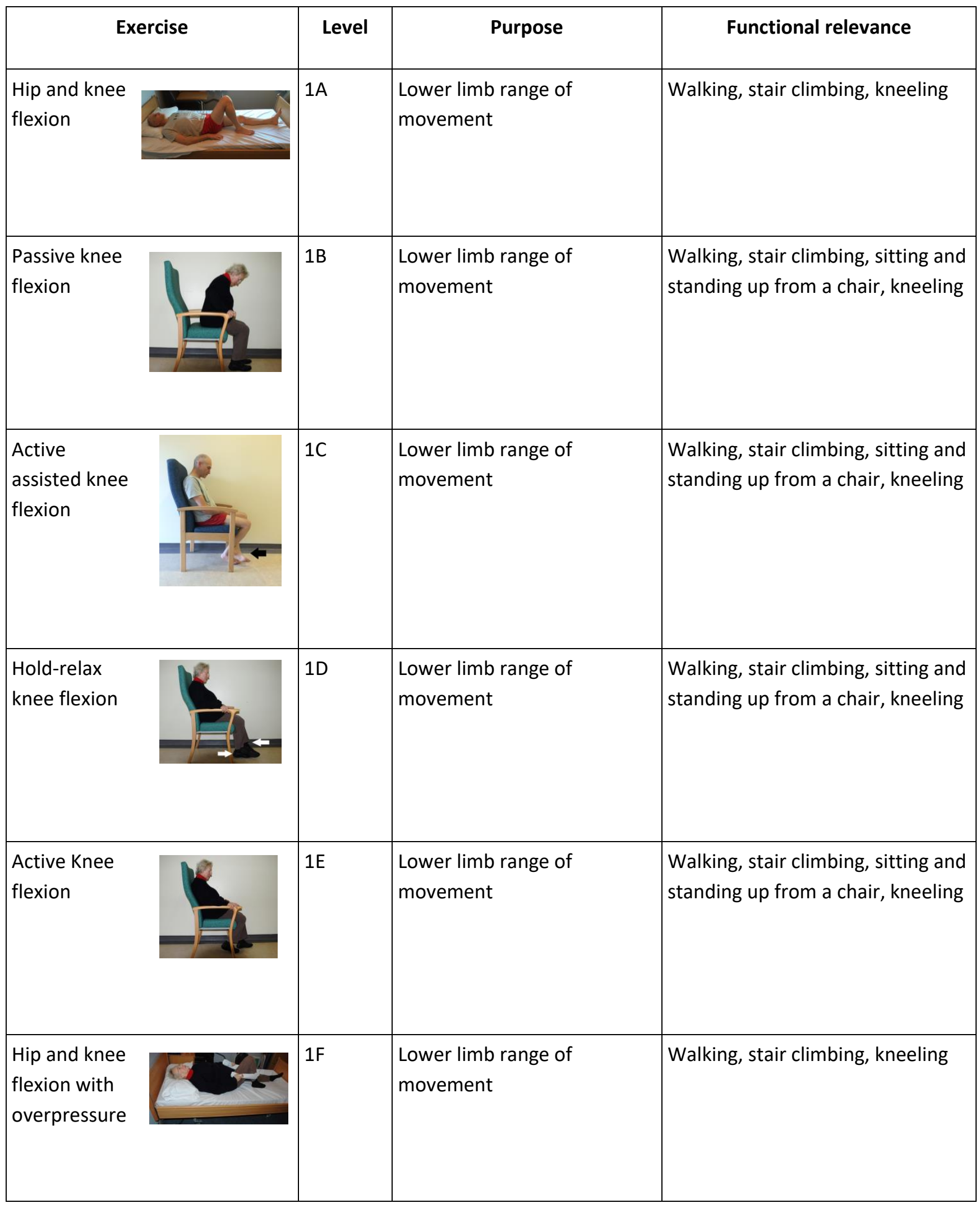




\begin{tabular}{|c|c|c|c|}
\hline $\begin{array}{l}\text { Knee } \\
\text { extension } \\
\text { stretch }\end{array}$ & $2 \mathrm{~A}$ & $\begin{array}{l}\text { Lower limb range of } \\
\text { movement }\end{array}$ & $\begin{array}{l}\text { Walking, stair climbing, standing } \\
\text { up from a chair }\end{array}$ \\
\hline $\begin{array}{l}\text { Knee } \\
\text { extension } \\
\text { with } \\
\text { overpressure }\end{array}$ & $2 B$ & $\begin{array}{l}\text { Lower limb range of } \\
\text { movement }\end{array}$ & $\begin{array}{l}\text { Walking, stair climbing, standing } \\
\text { up from a chair }\end{array}$ \\
\hline $\begin{array}{l}\text { Knee } \\
\text { extension }\end{array}$ & $2 \mathrm{C}$ & $\begin{array}{l}\text { Lower limb range of } \\
\text { movement }\end{array}$ & $\begin{array}{l}\text { Walking, stair climbing, standing } \\
\text { up from a chair, dressing, getting } \\
\text { in/out of car }\end{array}$ \\
\hline $\begin{array}{l}\text { Hamstring } \\
\text { stretch }\end{array}$ & 2D & $\begin{array}{l}\text { Lower limb range of } \\
\text { movement }\end{array}$ & Walking, stair climbing, dressing \\
\hline Calf stretch & $2 \mathrm{E}$ & $\begin{array}{l}\text { Lower limb range of } \\
\text { movement }\end{array}$ & Walking, stair climbing, dressing \\
\hline $\begin{array}{l}\text { Static } \\
\text { Quadriceps }\end{array}$ & $3 \mathrm{~A}$ & Lower limb strength & $\begin{array}{l}\text { Walking, stair climbing, standing } \\
\text { up from a chair }\end{array}$ \\
\hline $\begin{array}{l}\text { Inner range } \\
\text { quadriceps }\end{array}$ & 3B & Lower limb strength & $\begin{array}{l}\text { Walking, stair climbing, standing } \\
\text { up from a chair }\end{array}$ \\
\hline
\end{tabular}




\begin{tabular}{|c|c|c|c|}
\hline $\begin{array}{l}\text { Long arc } \\
\text { quadriceps }\end{array}$ & $4 \mathrm{~A}$ & Lower limb strength & $\begin{array}{l}\text { Walking, stair climbing, standing } \\
\text { up from a chair }\end{array}$ \\
\hline $\begin{array}{l}\text { Knee } \\
\text { extension } \\
\text { with ankle } \\
\text { weight }\end{array}$ & $4 \mathrm{~B}$ & Lower limb strength & $\begin{array}{l}\text { Walking, stair climbing, standing } \\
\text { up from a chair }\end{array}$ \\
\hline $\begin{array}{l}\text { Sit to stand } \\
\text { using arms }\end{array}$ & $4 C$ & $\begin{array}{l}\text { Upper and lower body } \\
\text { strength }\end{array}$ & $\begin{array}{l}\text { Walking, stair climbing, standing } \\
\text { up from a chair, lifting/carrying } \\
\text { household objects, getting in/out } \\
\text { of car }\end{array}$ \\
\hline $\begin{array}{l}\text { Sit to stand } \\
\text { without arms }\end{array}$ & 4D & $\begin{array}{l}\text { Lower limb and trunk } \\
\text { strength }\end{array}$ & $\begin{array}{l}\text { Stair climbing, standing up from a } \\
\text { chair, walking, getting in/out of } \\
\text { car }\end{array}$ \\
\hline Wall slide & $4 \mathrm{E}$ & Lower limb strength & $\begin{array}{l}\text { Stair climbing, standing up from a } \\
\text { chair, walking, getting in/out of } \\
\text { car, lifting household objects }\end{array}$ \\
\hline Mini Squats & $4 \mathrm{~F}$ & Lower limb strength & $\begin{array}{l}\text { Stair climbing, standing up from a } \\
\text { chair, walking, getting in/out of } \\
\text { car, lifting household objects }\end{array}$ \\
\hline
\end{tabular}




\begin{tabular}{|c|c|c|c|}
\hline Single leg dip & $4 \mathrm{G}$ & Lower limb strength & $\begin{array}{l}\text { Stair climbing, standing up from a } \\
\text { chair, walking, lifting household } \\
\text { objects }\end{array}$ \\
\hline $\begin{array}{l}\text { Static } \\
\text { hamstrings }\end{array}$ & $5 A$ & Lower limb strength & $\begin{array}{l}\text { Stair climbing, standing up from a } \\
\text { chair, walking, lifting household } \\
\text { objects }\end{array}$ \\
\hline $\begin{array}{l}\text { Sliding heel } \\
\text { backwards }\end{array}$ & $5 B$ & $\begin{array}{l}\text { Lower limb strength and } \\
\text { range of movement }\end{array}$ & $\begin{array}{l}\text { Stair climbing, standing up from a } \\
\text { chair, walking, kneeling }\end{array}$ \\
\hline $\begin{array}{l}\text { Standing } \\
\text { hamstring } \\
\text { curls }\end{array}$ & $5 C$ & Lower limb strength & $\begin{array}{l}\text { Stair climbing, standing up from a } \\
\text { chair, walking, lifting household } \\
\text { objects }\end{array}$ \\
\hline $\begin{array}{l}\text { Active } \\
\text { hamstrings }\end{array}$ & $5 \mathrm{D}$ & Lower limb strength & $\begin{array}{l}\text { Stair climbing, standing up from a } \\
\text { chair, walking, lifting household } \\
\text { objects }\end{array}$ \\
\hline $\begin{array}{l}\text { Standing } \\
\text { hamstring } \\
\text { curls with } \\
\text { ankle weight }\end{array}$ & $5 \mathrm{E}$ & Lower limb strength & $\begin{array}{l}\text { Stair climbing, standing up from a } \\
\text { chair, walking, lifting household } \\
\text { objects }\end{array}$ \\
\hline Lunge & $5 \mathrm{~F}$ & Lower limb strength & $\begin{array}{l}\text { Stair climbing, standing up from a } \\
\text { chair, walking, lifting household } \\
\text { objects }\end{array}$ \\
\hline
\end{tabular}




\begin{tabular}{|c|c|c|c|}
\hline $\begin{array}{l}\text { Hip } \\
\text { abduction }\end{array}$ & $6 \mathrm{~A}$ & Lower limb strength & $\begin{array}{l}\text { Walking, dressing, getting into/out } \\
\text { of bed }\end{array}$ \\
\hline Bridging & $6 B$ & Lower limb strength & $\begin{array}{l}\text { Dressing, walking, standing up } \\
\text { from a chair }\end{array}$ \\
\hline Hip hitching & $6 C$ & Lower limb strength & $\begin{array}{l}\text { Walking, dressing, getting into/out } \\
\text { of bed }\end{array}$ \\
\hline $\begin{array}{l}\text { Standing hip } \\
\text { abduction }\end{array}$ & $6 \mathrm{D}$ & Lower limb strength & $\begin{array}{l}\text { Walking, dressing, getting into/out } \\
\text { of bed, standing from a chair }\end{array}$ \\
\hline $\begin{array}{l}\text { Standing hip } \\
\text { abduction } \\
\text { with ankle } \\
\text { weight }\end{array}$ & $6 \mathrm{E}$ & Lower limb strength & $\begin{array}{l}\text { Walking, dressing, getting into/out } \\
\text { of bed, standing from a chair }\end{array}$ \\
\hline $\begin{array}{l}\text { Short lever } \\
\text { hip abduction } \\
\text { in side lying }\end{array}$ & $6 \mathrm{~F}$ & Lower limb strength & $\begin{array}{l}\text { Walking, dressing, getting into/out } \\
\text { of bed }\end{array}$ \\
\hline $\begin{array}{l}\text { Long lever } \\
\text { hip abduction } \\
\text { in side lying }\end{array}$ & $6 \mathrm{G}$ & Lower limb strength & $\begin{array}{l}\text { Walking, dressing, getting into/out } \\
\text { of bed }\end{array}$ \\
\hline $\begin{array}{l}\text { Hip } \\
\text { abduction in } \\
\text { side lying } \\
\text { with ankle } \\
\text { weight }\end{array}$ & $6 \mathrm{H}$ & Lower limb strength & $\begin{array}{l}\text { Walking, dressing, getting into/out } \\
\text { of bed }\end{array}$ \\
\hline
\end{tabular}




\begin{tabular}{|c|c|c|c|}
\hline $\begin{array}{l}\text { Bilateral calf } \\
\text { raise }\end{array}$ & $7 A$ & Lower limb strength & Walking and stair climbing \\
\hline $\begin{array}{l}\text { Single calf } \\
\text { raise }\end{array}$ & $7 \mathrm{~B}$ & Lower limb strength & Walking and stair climbing \\
\hline $\begin{array}{l}\text { Standing feet } \\
\text { together }\end{array}$ & $8 \mathrm{~A}$ & Balance & Falls Prevention \\
\hline $\begin{array}{l}\text { Semi-tandem } \\
\text { stance }\end{array}$ & $8 \mathrm{~B}$ & Balance & Falls prevention \\
\hline $\begin{array}{l}\text { Tandem } \\
\text { stance }\end{array}$ & $8 C$ & Balance & Falls Prevention \\
\hline $\begin{array}{l}\text { Single leg } \\
\text { stance }\end{array}$ & $8 \mathrm{D}$ & Balance & Falls Prevention \\
\hline $\begin{array}{l}\text { Walking on } \\
\text { the spot }\end{array}$ & $9 \mathrm{~A}$ & Walking skills and balance & Walking and falls prevention \\
\hline
\end{tabular}




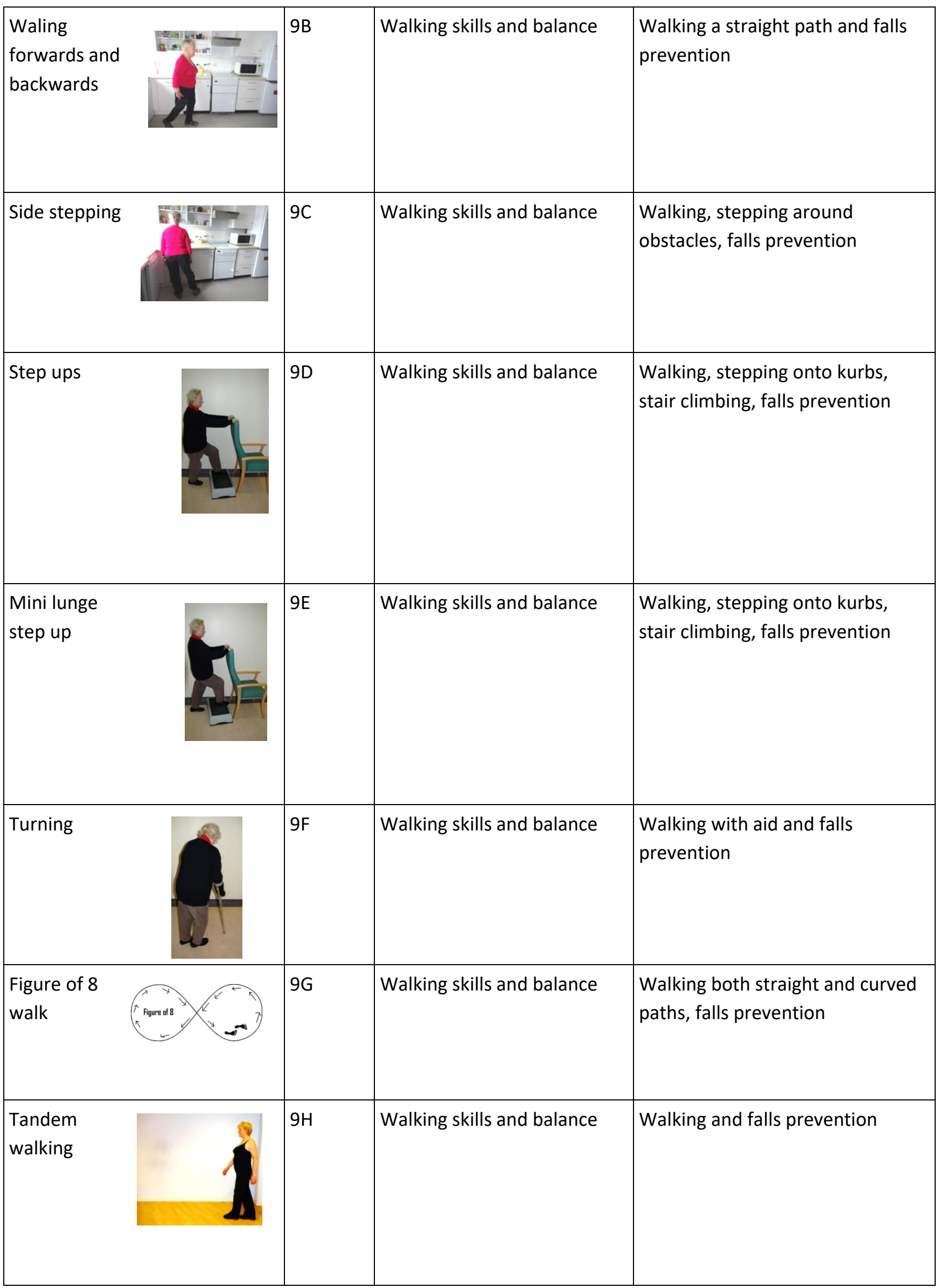

